\title{
The Effectiveness of Indirect Correction Method Aided by Correction Codes
}

\author{
Kartika Stela', Julia Wulandari² \\ Universitas Indonesia \\ Email: kartikastela@gmail.com
}

Submitted: $23 / 06 / 2020$

Revised: 04/11/2020

Accepted: 17/01/2021

\begin{abstract}
This research discusses the effectiveness of indirect correction method supported by Karin Kleppin's correction codes on writing assignments. The research participants were FIB Ul's German Studies Program students from the German Language IV course. This research aims to evaluate the effectiveness of this method in helping students recognize and correct morphological and syntactic errors. This is done by comparing the number of errors and analyzing them with the highest and lowest percentages of successful correction. Meanwhile, the effectiveness of this method in minimizing errors during the research was explored quantitatively by comparing the number of errors. The three corpora analysed in this research were the pretest, correction, and posttest writing assignments. The results indicate that punctuation, subjunctive mood, and grammatical case are the errors that had the highest percentages of successful correction, while errors modal verb, sentence structure, and missing elements had the lowest percentage of successful correction. 12 out of 15 errors analysed in this research were successfully recognized and corrected by at least $50 \%$ of all participants. Thus, this method can be said to be quite effective in recognizing and correcting errors. However, the effectiveness of this method in minimizing errors in the posttest did not bear significant results as only 16 out of 37 participants (43\%) experienced a reduction in the number of errors.
\end{abstract}

Keywords: indirect correction, correction code, writing assignment, morphological and syntactical errors, German as a foreign language

\section{https://ojs.unm.ac.id/eralingua}




\section{INTRODUCTION}

The writing process in a foreign language is more complex since language learners must apply their knowledge of phonetics, morphology, grammar, and vocabulary simultaneously. Thus, it is normal and common for language learners to make errors (Gračner, 2018). However, making errors is an important part of foreign language learning (Ondráková \& Pazlarová, 2017; Klambauer, 2019). Kleppin (2002) argues that one can learn from errors if consciously involved in correcting them. In practice, however, learners are rarely involved directly in correcting their errors, especially in writing assignments. Teachers usually only mark the errors or directly correct them. Only a few learners are critical by attempting to analyze why their sentences are incorrect, or why such correction is given. As a result, learners are more likely to easily forget the correction given and to only remember what they have written, which is incorrect. Klambauer (2019) and Brachmann-Bosse (2019) in their study stated that from the didactic point of view, it is crucial not to regard errors as negative things, rather as a means of learning. One way to engage learners with errors is indirect correction. Several studies on indirect correction in foreign language learning (Balderas \& Cuamatzi, 2018; Pujiawati, 2018) have shown that involving learners in indirect correction plays a vital role and brings positive impacts, such as increasing learners' motivation, making learners feel responsible for the learning process, consciously correcting errors, and shaping learners to become more independent. Therefore, indirect correction can be applied in improving writing skills.

One way to apply indirect correction is the use of correction codes. Correction codes are a tool to identify mistakes in writing tasks in a foreign language, which is German in this regard. Correction codes become reference for correcting the errors that have been marked, with the hope that the same errors will not be repeated in the future. Indirect correction assisted by correction codes is not new in learning German as a foreign language (Koeva, 2019). Kalkan (2018) and Pedrazzini (2018) mentioned that correction codes serve as an impulse for learners to be consciously involved in the processes of classification, identification, and correction of the errros that they have made. Despite time-consuming and labor-intensive, this method is found to be useful in correcting grammatical errors, provided that learners have studied the grammar rules concerned. However, the results of these studies cannot be generalized because they are influenced by some factors, such as the types of mistakes, the research objectives, and the characteristics of each learner (Miniböck, 2018; Kanzian, 2019; Klemm, 2019).

The aforementioned previous studies involved various participants: language learners of German as a first and second language at the school level, language classes of German as a foreign language for college preparation, and German language students (Education) at the university level. Most of the research were conducted on participants with advanced level of German. On the other hand, research on participants with elementary level of German have also been conducted (Perdamean, 2017). Thus, the current study focuses on the students of German Studies Program at the intermediate level who have learned sufficient grammar. This study, however, is centered only on the types of errors at the morphological and syntactical levels. Some previous studies (Buckingham \& Aktuğ-Ekinci, 2017; Fang \& 
Freudenberg-Findeisen, 2019) found that other types of errors, such as lexicons and expressions, are difficult to be corrected due to the learners' lack of required language knowledge. This study was conducted with an aim to investigate if the indirect correction method with the aid of correction codes is effective in assisting participants in the identification and correction of errors by combining qualitative error analysis and quantitative data. Further, the effectiveness of this method in minimizing the number of errors during the research period was also evaluated.

\section{RESEARCH METHOD}

The combination of qualitative and quantitative methods was employed in this research in order to analyze data comprised of three writing assignments: pretest, correction, and posttest, and to examine the effectiveness of indirect correction assisted by correction code. The effectiveness in this research was examined from two standpoints. First, to investigate the effectiveness of indirect method in helping participants recognize and correct errors, the researchers compared the number of pretest errors with correction, and to analyze the types of errors with the highest and lowest percentages of successful corrections. Error analysis was performed to look at which type of errors that was relatively easy and difficult to be recognized and corrected. Second, to evaluate whether the method was effective in writing skill and in reducing errors over the course of the research, the researchers compared the number of pretest and posttest errors.

The initial participants of this study were all 50 students from two classes taking the German Language IV Course at the Faculty of Humanities, University of Indonesia in the even semester of the 2018/2019 academic year. The students of the German Language IV Course were chosen because they were considered to have sufficient knowledge of basic German grammar, and at the time of data collection they had completed B1 level materials (Common European Framework of Reference for Languages). The final number of participants taking the three stages of the study (pretest, correction, and posttest) was 37 students. The initial participants, who only participated in the two stages of the study, were not analyzed. At the pretest and posttest stages, participants were asked to write a reply letter of 100-150 words about a topic closely related to their everyday lives. Meanwhile, at the correction stage, participants were asked to make corrections for the pretest results that had been given correction codes. In all the three stages, participants were given 30 minutes and not allowed to use any tools, but at the correction stage, participants were given a guide paper containing a table of correction codes along with definitions and example sentences for each type.

\section{RESULTS AND DISCUSSION}

Kleppin (2002) divided written correction (schriftliche Korrektur) into four correction stages (Korrektursequenz) that can be flexibly combined or used without being dependent on one stage to another. The four correction stages are: regular error marking, error marking with correction codes, error correction by the teacher, and independent error correction by the learner. Two of the stages of written correction were used in this study, namely error marking with correction codes and independent error correction by the learner. This study employed the correction 
codes by Kleppin who classified correction codes based on the types of errors, which are presented in the following table.

Table 1. Correction Codes by Kleppin

A Ausdruck (Expressions), example:

Sie machte den ersten Fuß. (instead of: den ersten Schritt)

Translation: She made the first step.

Bez syntaktischer oder semantischer Bezug (syntactic and semantic

references), example:

Die Frau arbeitete in der Fabrik seines (instead of: ihres) Mannes.

Translation: The woman worked at her husband's factory.

Ich gibt (anstatt: gebe) es zu.

Translation: I admit it.

Gen Genus, example:

Zwischen England und Frankreich liegt nur die (instead of: der) Kanal.

Translation: Between England and France there is only that canal.

K Kasus (Case), example:

Aus religiöse Gründe (instead of: aus religiösen Gründen) ist das nicht

möglich.

Translation: For religious reasons it is impossible.

Konj Konjunktion (Conjunction), example:

Wenn (instead of: als) ich gestern aufwachte.

Translation: When I woke up yesterday.

M Modus (Subjunctive mood), example:

Wenn ich reich war (instead of: wäre), würde ich nach Deutschland in

Urlaub fahren.

Translation: If I were rich, I would visit Germany for holiday.

mF morphologischer Fehler (Morphological error), example:

Das Gebirge erhebte (instead of: erhob) sich vor mir.

Translation: (At that time) the mountains loomed before me.

Mv Modalverb (Modal verbs), example:

Du musst hier nicht rauchen. (instead of: darfst)

Translation: You must not (instead of: are not allowed to) smoke here.

Präp Präposition (Preposition), example:

Ich kümmere mich über (instead of: um) die Kinder.

Translation: I take care of the children.

Pron Pronomen (Pronoun), example:

Ich habe dem (instead: ihm) geholfen.

Translation: I helped him.

R Rechtschreibung (Orthography), example:

Wenn Man (instead of: man) jemanden begrüßt, ...

Translation: If a person greets someone, ...

Sb Satzbau (Sentence structure), example: 


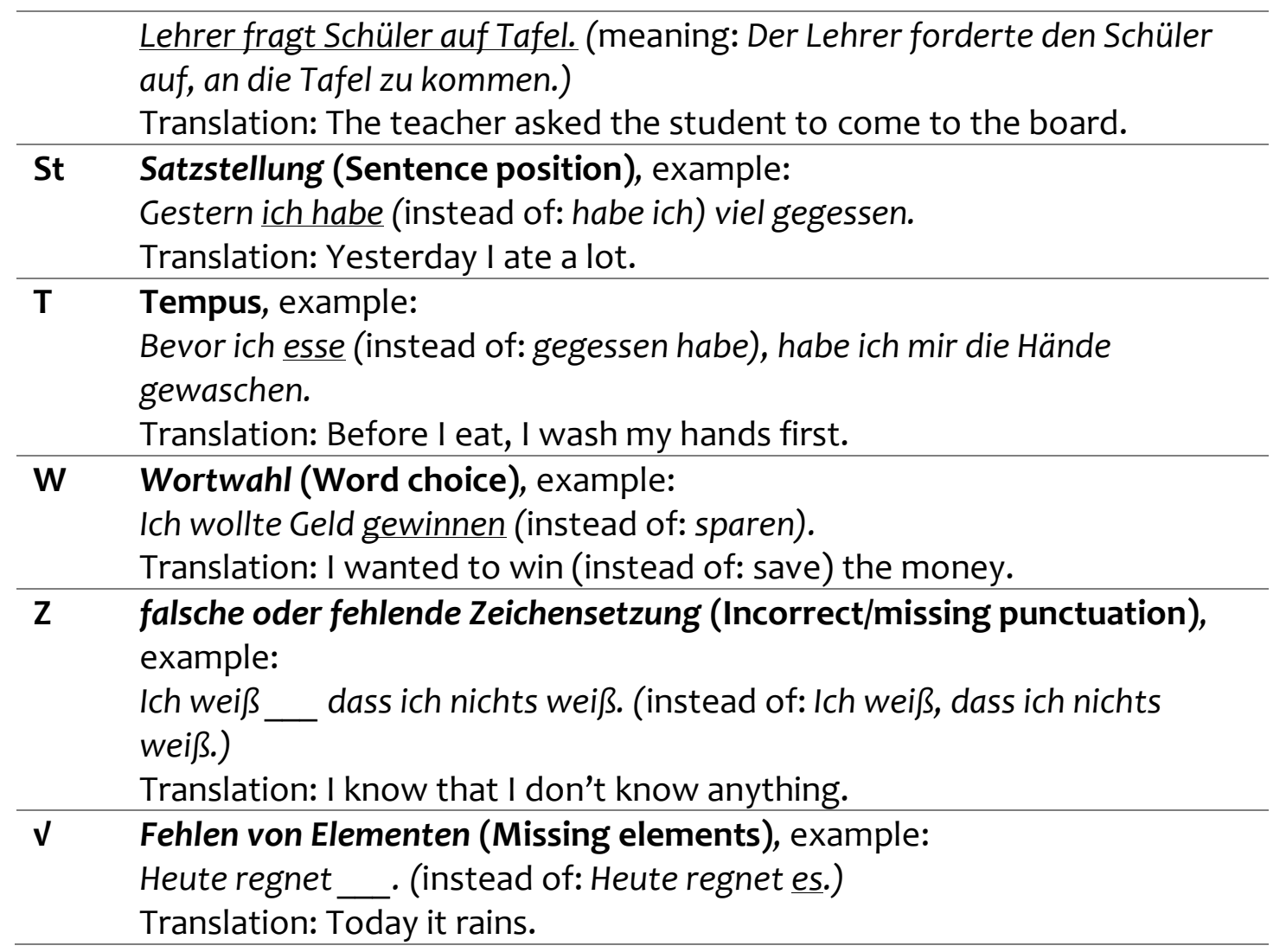

Source: Kleppin (2002, p. 45-47)

Since this study is focused on the types of errors at the morphological and syntactic levels, the error marking involved: semantic/syntactic references, genus, case, conjunction, subjunctive mood, morphological errors, modal verbs, preposition, pronouns, orthography, sentence structures, tempus, punctuation, and missing elements. According to Kleppin (2002), errors that can be independently corrected by the learner are usually errors at the morphological and syntactic levels, such as morphological errors in Endungen or the suffix in verb conjugation, and the syntactic errors in word placement in sentences. To find out the extent to which participants could recognize and correct error independently aided by correction codes, the number of errors in the pretest and correction stages was compared. The results can be seen as follows.

Table 2. Comparison of the number of errors in the pretest and correction stages

\begin{tabular}{clccc}
\hline No. & Types of Errors & \multicolumn{2}{c}{ Number } & $\begin{array}{c}\text { Percentages of errors } \\
\text { that can be corrected }\end{array}$ \\
\cline { 2 - 4 } & Pretest & Correction & $75 \%$ \\
\hline 1. & $\begin{array}{l}\text { Semantic/syntactic } \\
\text { references }\end{array}$ & 83 & 21 & $52 \%$ \\
\hline 2. & Genus & 31 & 15 & $80 \%$ \\
\hline 3. & Case & 50 & 10 & $56 \%$ \\
\hline 4. & Conjunction & 9 & 4 & $80 \%$ \\
\hline 5. & Subjunctive mood & 10 & 2 & $67 \%$ \\
\hline 6. & Morphological error & 12 & 4 & \\
\hline
\end{tabular}




\begin{tabular}{clccc}
\hline 7. & Modal verb & 1 & 1 & $0 \%$ \\
\hline 8. & Preposition & 26 & 6 & $77 \%$ \\
\hline 9. & Pronoun & 4 & 2 & $50 \%$ \\
\hline 10. & Orthography & 86 & 32 & $63 \%$ \\
\hline 11. & Sentence structure & 32 & 21 & $34 \%$ \\
\hline 12. & Sentence position & 59 & 17 & $71 \%$ \\
\hline 13. & Tempus & 10 & 4 & $60 \%$ \\
\hline 14. & Punctuation & 46 & 5 & $89 \%$ \\
\hline 15. & Missing element & 49 & 25 & $49 \%$
\end{tabular}

It can be seen from the table above that most errors had a successful correction rate of at least $50 \%$. The three types of errors with the highest percentages of successful correction were punctuation ( $89 \%)$, subjunctive mood (80\%), and cases (80\%). Meanwhile, the types of errors with the lowest successful correction rates were modal verb (0\%), sentence structure (34\%), and missing element (49\%).

\section{Errors with the highest successful correction rate}

The three types of errors discussed in this part are incorrect or missing punctuation (Fehlende oder falsche Zeichensetzung) marked with the letter Z; incorrect mood (Falscher Modusgebrauch) marked with the letter M; and incorrect case (Falscher Kasus) marked with the letter K. These three types of errors had the highest percentages of successful correction by comparing the number of similar errors at the pretest and correction stages.

\section{a. Incorrect or missing punctuation (Zeichensetzung)}

This type of error occurs when punctuation is incorrect or missing in a sentence. This type of error had the highest percentage of successful correction. In the pretest, there were 46 items of incorrect or missing punctuation. A total of 41 errors ( $89 \%$ ) could be corrected at the correction stage. This type of error is quite easy to identify because it mostly involves putting a comma before a conjunction. Most German language learners tend to ignore the use of commas despite their importance. Based on the rules for the use of commas (Dreyer \& Schmitt, 2013), a comma in German must be placed between the independent clause and dependent clause (subjunctions such as wenn, dass, obwohl, etc.); between two main sentences connected with a coordinating conjunction position such as aber and a conjunctional adverb such as deshalb; and before or after Infinitivkonstruktion. The following are three sentences that contain punctuation errors.

Table 3. Examples of incorrect or missing punctuation

\begin{tabular}{llll}
\hline No. & $\begin{array}{l}\text { Participants' sentences } \\
\text { in the pretest }\end{array}$ & $\begin{array}{l}\text { Participants' sentences } \\
\text { in the correction }\end{array}$ & Translation \\
\hline 1. & $\begin{array}{l}\text { Ich finde es gut und } \\
\text { praktisch weil unser }\end{array}$ & $\begin{array}{l}\text { Ich finde es gut und } \\
\text { praktisch, weil unser }\end{array}$ & $\begin{array}{l}\text { I think, it's good and } \\
\text { practical because our } \\
\text { Haus ... }\end{array}$ \\
\end{tabular}




\begin{tabular}{llll}
\hline 2. $\begin{array}{l}\text { Ich finde Bali überfullt } \\
\text { aber nicht so überfullt } \\
\text { wie Jakarta. }\end{array}$ & $\begin{array}{l}\text { Ich finde Bali überfullt, } \\
\text { aber nicht so überfullt } \\
\text { wie Jakarta. }\end{array}$ & $\begin{array}{l}\text { I think, Bali is very } \\
\text { crowded, but not as } \\
\text { crowded as Jakarta. }\end{array}$ \\
\hline $\begin{array}{lll}\text {... brauche nur wenige } \\
\text { Geld um Transportation } \\
\text { zu zahlen. }\end{array}$ & $\begin{array}{l}\text {.. brauche nur wenige } \\
\text { Geld, um Transportation } \\
\text { zu zahlen. }\end{array}$ & $\begin{array}{l}\text {... only need a little } \\
\text { money to pay for } \\
\text { transportation. }\end{array}$ \\
\hline
\end{tabular}

1. Ich finde es gut und praktisch weil unser Haus ...

In this sentence, a participant combined two sentences Ich finde es gut und praktisch and unser Haus ... with the subjunction weil to show the cause and effect. Weil is a subjunction that connects an independent clause and a dependent clause, so a comma should be used after the word praktisch.

2. Ich finde Bali überfullt aber nicht so überfullt wie Jakarta.

In this sentence, a participant joined two clauses consisting of Ich finde Bali überfüllt and Bali ist nicht so überfüllt wie Jakarta with the conjunction aber. Aber is a coordinating conjunction, so a comma should be placed right after the first überfullt.

3. ... brauche nur wenige Geld um Transportation zu zahlen.

This sentence uses the Infinitivkonstruktion structure um ... zu. A comma should be put before the word um because um ... zu separates the independent clause from the dependent clause.

These errors are relatively easy to be corrected because only addition or replacement of punctuation is necessary; and errors usually occur due to the learner's carelessness that in German, a comma is needed, for instance, to link an independent clause with a dependent clause. The $\mathrm{Z}$ letter used to mark punctuation errors between the words praktisch and weil, überfullt and aber, as well as Geld and um allowed participants to learn that a punctuation mark was missing and that they could correctly add a comma between those words.

\section{b. Mood errors (Modus)}

This error occurs when a mood is incorrectly used in a sentence. German recognizes three moods: Indikativ (Wirklichkeitsform), Konjunktiv (Möglichkeitsform), and Imperativ (Befehlsform), which can be distinguished by certain verb forms. Konjunktiv is divided into Konjunktiv I and Konjunktiv II, but at the German IV level, which is equivalent to the B1 level, participants had not learned about Konjunktiv I mood; thus, the errors found were related to the moods of Indikativ and Konjunktiv II. These two moods are used to distinguish between sentences showing reality (Indikativ) and sentences showing possibility (Konjunktiv) (Dreyer dan Schmitt, 2013).

In the pretest, 10 mood errors were found and $80 \%$ of the errors (a total of 8 errors) can be corrected. There was a trigger question "Was würden Sie an Sebastians Stelle tun?" that means "What would you do if you were in Sebastian's position?" This question uses a Konjunktiv II verb, which is würde, and asks for a conditional answer, which should also use the Konjunktiv moodd, more precisely Konjunktiv II. The following is the analyisis of three sentences that contain mood errors. 
Table 4. Examples of mood errors

\begin{tabular}{|c|c|c|c|}
\hline No. & $\begin{array}{l}\text { Participants' sentences } \\
\text { in the pretest }\end{array}$ & $\begin{array}{l}\text { Participants' sentences in } \\
\text { the correction }\end{array}$ & Translation \\
\hline 1. & $\begin{array}{l}\text { Wenn du deine eigene } \\
\text { Wohnung hast, könntest } \\
\text { du... }\end{array}$ & $\begin{array}{l}\text { Wenn du deine eigene } \\
\text { Wohnung hättest, } \\
\text { könntest du ... }\end{array}$ & $\begin{array}{l}\text { If you had your own } \\
\text { house, you could ... }\end{array}$ \\
\hline 2. & $\begin{array}{l}\text { Wenn ich an deiner Stelle } \\
\text { bin, ... }\end{array}$ & $\begin{array}{l}\text { Wenn ich an deiner Stelle } \\
\text { wäre, ... }\end{array}$ & $\begin{array}{l}\text { If I were in your } \\
\text { shoes, ... }\end{array}$ \\
\hline 3. & $\begin{array}{l}\text { Ich hätte auch das } \\
\text { Problemam Anfang. }\end{array}$ & $\begin{array}{l}\text { Ich hatte auch das Problem } \\
\text { am Anfang. }\end{array}$ & $\begin{array}{l}\text { I also had the same } \\
\text { problem at first. }\end{array}$ \\
\hline
\end{tabular}

1. Wenn du deine eigene Wohnung hast, könntest du ...

The conditional sentence above means "If you had your own house, you could ..." The participant already used Konjunktiv II (könntest) in the independent clause, but did not use it in the dependent clause. The dependent clause should use the Konjunktiv II verb "hättest", not "hast" which is the Indikativ verb.

2. Wenn ich an deiner Stelle bin, ...

Similar with the sentence in number 1 , the sentence above is also conditional, meaning "If I were in your shoes, ..." Thus, the Konjunktiv II mode and the verb ware should be used, not the verb bin which is the Indikativ mode.

3. Ich hätte auch das Problem am Anfang.

This sentence means that at first he/she had the same problem with the person in the story, so this sentence should not be written in Konjunktiv II, but instead in the Indikativ past form, which is hatte, not hätte.

These mood errors can be easily corrected because most participants can quickly recognize and replace the mood used in the sentence. The Konjunktiv II mood is part of the learning materials that have recently been given in the class, so the errors occurred due to the lack of habituation using this mood to write conditional sentences or the participants' carelessness in writing resulting in the use of inaccurate moods. As the errors were marked by being underlined and given the $M$ letter, most participants learned that they were using incorrect moods.

c. Case errors

This type of error occurs when an incorrect case is used. German has four cases, namely Nominativ, Akkusativ, Dativ, and Genitiv. Cases in German function to show the morphological relationship between nouns and other elements in a sentence (Helbig \& Buscha, 1996). For instance, the Akkusativ case is used to show adverbs of time, which can be seen in the phrase jeden Tag or nächsten Monat. One common way used to identify cases in a sentence is to look at the verb and/or preposition. For example, the prepositions bei and bon are always followed by the Dativ case, while the preposition in is Wechselpräposition, which can use the Dativ case to show location (Wo?) and the Akkusativ case to show movement (Wohin?). Most verbs in German are Akkusativ, such as bekommen and besuchen. Some verbs 
can only be followed by Dativ case, such as gratulieren and gefallen, and some other verbs are usually followed by Dativ and Akkusativ cases, such as geben, schenken, and erzählen.

The Genitiv case also has certain verbs that determine cases such as gedachten and sich erinnerten, but these verbs have no longer been widely used, so now the Genitiv case is more highly determined by prepositions such as angesichts and während, or by context since this case can be used to show possession (Pittner \& Berman, 2010). For example, in the sentence "Das ist der Hund meiner Tante", the Possessivartikel mein has the Genitiv case to show that the dog is my aunt's dog. In the pretest, 50 errors in the use of cases were found, but $80 \%$ (a total of 40 errors) can be corrected. The analysis of the four sentences containing case errors is shown in the table below.

Table 5. The examples of case errors

\begin{tabular}{llll}
\hline No. & $\begin{array}{l}\text { Participants' sentences } \\
\text { in the pretest }\end{array}$ & $\begin{array}{l}\text { Participants' sentences } \\
\text { in the correction }\end{array}$ & Translation \\
\hline 1. & $\begin{array}{l}\text { Mir geht's gut, und du?; } \\
\text { Wie geht es dir und deine }\end{array}$ & $\begin{array}{l}\text { Mir geht's gut, und dir?; } \\
\text { Wie geht es dir und deiner am fine, and you? } \\
\text { Freundin? }\end{array}$ & $\begin{array}{l}\text { How are you and your } \\
\text { girlfriend? }\end{array}$ \\
\hline 2. & $\begin{array}{l}\text { In meinem Land wohnen } \\
\text { die jungen Leute mehr in } \\
\text { eine Wohnung. }\end{array}$ & $\begin{array}{l}\text { In meinem Land wohnen } \\
\text { die jungen Leute mehr in } \\
\text { einer Wohnung. }\end{array}$ & $\begin{array}{l}\text { In my country, young } \\
\text { people mostly live in }\end{array}$ \\
\hline 3. & $\begin{array}{l}\text { Ich habe letzte Monat ein } \\
\text { Job ... bekommt. }\end{array}$ & $\begin{array}{l}\text { Ich habe letzte Monat } \\
\text { einen Job ... bekommt. }\end{array}$ & I got a job last month. \\
\hline 4. & Bei meiner Eltern & Bei meinen Eltern & With my parents. \\
\hline
\end{tabular}

1. Mir geht's gut, und du?; Wie geht es dir und deine Freundin?

The sentence above is used to express good condition and ask back how someone is doing. In this case, the verb gehen needs Pronomen es and must be followed by a Dativ object and a modal specification (Modalangabe) if the sentence is a statement (Helbig \& Buscha, 1996). When meeting with Pronomen es, the verb gehen experiences a change in meaning from Bewegung or its movement to become an expression used to ask or state how a person is. The question after "und" still uses the same verb es geht, so du and deine Freundin should be written with the Dativ case, which is similar with mir and dir. Thus, the correct sentences should read "Mir geht's gut, und dir?" and "Wie geht es dir und deiner Freundin?".

2. In meinem Land wohnen die jungen Leute mehr in eine Wohnung.

The preposition in used in the sentence above is Wechselpräposition, meaning that it can have two cases: Akkusativ and Dativ. The Dativ case applies for the preposition in when in the sentence it means "in" in English, while the Akkusativ case applies when it means "to" in English. Since the sentence above provides the context "in an apartment", it is the word einer, not eine, that should be used to indicate the Dativ case. 
3. Ich habe letzte Monat ein Job ... bekommt.

In the sentence above, the verb bekommen is a verb that does not need an Akkusativ object, while the word Job is an Akkusativ object. Then, the word ein should be replaced with the word einen because the word Job has the article der, and in the Akkusativ case, der turns into den. The word letzte is also used incorrectly because letzten Monat in the sentence above shows an adverb of time. Thus, the Akkusativ case should also be applied.

\section{Bei meiner Eltern}

The phrase above means someone lives with their parents. This error occurred frequently in the pretest. In the sentence above, the error lies in the word meiner. The Dativ case in the above phrase was used correctly, but it became less precise due to the declension error in the possessive pronoun mein. The word Eltern is a plural noun with the article die, so declension should be performed on the possessive pronoun mein with the suffix -en, instead of -er. The suffix -er only applies to nouns with the singular article die. The error above is categorized into a case error because it is usually associated with dative plural.

Most errors are caused by carelessness, such as the incorrect use of the dative and accusative cases in Wechselpräpositionen and the adjective declensions on plural nouns. Thus, these errors can be easily corrected. With the letter K used to mark the errors, participants can tell that they were using the wrong case.

\section{Errors with the lowest successful correction rates}

The three types of errors discussed in this part had the lowest percentages of successful correction, including errors in using modal verbs marked with "Mv"; sentence structure (Satzbau) marked with "Sb"; and elements missing from a sentence (Fehlen von Elementen) marked with " $\mathrm{v}$ ".

\section{a. Errors in using modal verbs}

This type of error occurs when a modal verb is used incorrectly in a sentence. German has 6 modal verbs: müssen, können, dürfen, sollen, wollen, and mögen that have different meanings in their usage. An error in using a modal verb was found in the pretest, and it could not be successfully corrected. Thus, the successful correction rate of this error was $0 \%$. The following is the analysis of the sentence containing the error in the modal verb.

Am besten musst du mit deinen Eltern (sprechen).

Translation: Ideally you have to talk to your parents.

The sentence above means that the subject du has to talk to his or her parents. The modal verb used in that sentence is müssen, which functions to express compulsion and necessity (Dreyer and Schmitt, 2013). Meanwhile, the sentence above aims to give advice to du; the modal verb sollen should be used instead. The modal verb sollen is used to give orders or suggestions to other people. This type of error is difficult to be corrected if participants have not adequately understood the function of each modal verb. 


\section{b. Errors in sentence structure (Satzbau)}

This type of error occurs when a sentence is difficult to understand due to the simultaneous occurrence of many errors. This study found many errors in sentence formulation which, in fact, can be understood literally in Indonesian, is not in accordance with German grammar rules. This may be caused by the participants' ignorance of the German sentence structures. In the pretest, 32 errors were found, but only $34 \%$ (a total of 11 errors) could be corrected. The analysis of the three sentences containing errors in sentence structures can be seen below.

1. Ich bin sehr gut und auch meine Familie. (Translation: My family and I are doing very well.)

This error occurred quite often; some participants could correct it, but some others could not. The sentence above is the answer to the question "Wie geht es dir und deiner Familie?", intended to ask how someone is doing. To answer this question, a rather different structure is needed. In Indonesian, the answer can be "Saya dan keluarga saya baik-baik saja", which is translated into German "Ich und meine Familie sind gut"; however, this translation is incorrect. These expressions should be used instead: "Es geht mir und meiner Familie sehr gut" or "Uns geht's sehr gut" where the dative case is applied.

2. Ich hoffe alles gut. (Translation: I hope everything is fine.)

This sentence is structurally incorrect. In Indonesian, the sentence above means "Saya berharap semuanya baik-baik saja", but an additional conjunction is needed to adhere to German grammar rules. Thus, it can be corrected by adding the subjunction dass and a new verb to connect the two clauses. The correct sentence should become Ich hoffe, dass alles gut geht, or Ich hoffe, dass alles gut ist.

3. Aber es gibt auch die jungen Leute allein wohnen. (Translation: But there are also young people who live alone.)

The sentence above means that there are young people who live alone. In German, two verbs are not allowed in one clause, except certain cases, such as Infinitivkonstruktion, verbs with infinitive, future tense, or modal verbs. The sentence above has two verbs, namely gibt and wohnen. These two verbs do not belong to any category mentioned earlier, so those two verbs cannot go together in one main clause. One way to correct this sentence is by using Relativsatz, so the sentence should be Aber es gibt auch junge Leute, die allein wohnen.

The examples above show that this type of errors is quite difficult to be corrected because the correction involves not only replacing one or two words, but also formulating different sentences and requiring sufficient knowledge of the differences of sentence structures between German and Indonesian. Only a few participants could correct this type of errors.

\section{c. Errors due to missing elements (Fehlen von Elementen)}

This type of errors occurs when some elements are missing from a sentence. The elements include pronouns (Pronomen), articles, prepositions, verbs, etc. The errors can result from various reasons, from carelessness and ignorance to language interference. In the pretest, 49 errors of this type were found, but only $49 \%$ (a total 
of 24 errors) could be corrected. The following are the analyses of four sentences containing missing elements.

1. Ich habe mich sehr über deine E-Mail. (Translation: I really ... about your e-mail.)

The sentence above is missing the verb in the Partizip II form at the end of the sentence. Tt should mean "I am really excited about your e-mail." Thus, the past form of the verb sich freuen should be put at the end of the sentence. The verb haben in the sentence above only functions as hilfsverb to form perfect tense sentences. The correct sentence should be: Ich habe mich sehr über deine E-Mail gefreut.

2. Du solltest sehr Glück fühlen. (Translation: You should feel very happy.)

The sentence above reveals that the subject du should feel happy. The element mssing from the sentence is the reflexive pronoun dich from the verb sich fühlen. The use of the word Glück is inaccurate because the sentence with the verb sich fühlen needs an adverb. The adverbial form of the Glück is glücklich. Therefore, the correct sentence is Du solltest dich sehr glücklich fühlen.

3. Meine Meinung du sollst von ... (Translation: In my opinion, you should ...)

The sentence above conveys an opinion with an expression "Meiner Meinung nach ..." followed by a verb. This sentence indicates that participants were strongly influenced by the Indonesian language structure "Menurutku kamu seharusnya ...". The missing element is the preposition nach, resulting in the shifting of the position of the verb. In fact, the preposition nach in the sentence must be followed by the verb, not the subject $d u$. Thus, the sentence should be corrected into Meiner Meinung nach sollst du ...

4. Hier ist nicht ruhig. (Translation: It's not quiet here.)

The missing element in the sentence is the personal pronoun es. The structure of this sentence also seems to be closely similar with the structure of Indonesian colloquialism, which says "Di sini tidak tenang" (It's not quiet here), or more commonly "Di sini berisik" (It's noisy in here). In Indonesian, the sentence is often used informally. In German, however, this sentence is grammatically incorrect due to the missing subject. The personal pronoun es is needed to be the subject in the sentence. Thus, the correct sentence should be Hier ist es nicht ruhig.

The examples above suggest that this type of errors is quite difficult to be corrected due to the structural differences between German and the participants' first language. Moreover, the participants' sentences in numbers 2-4 are seemingly literal translation from Indonesian whose sentence structures are different from German sentence structures. Only a few participants could easily understand this type of error and correct it.

\section{The effectiveness of indirect correction method aided by correction codes during the course of the study}

The analyses of errors presented above indicate that there are some morphological and syntactic errors that can be easily corrected with the help of correction codes, but some errors cannot be easily corrected and even recognized. 
The comparison of the number of errors between the pretest and correction stages, in which the rate of successful correction 12 out of 15 types of errors was above $50 \%$, signifies that the use of correction codes in indirect correction method can be quite effective in assisting participants in recognizing and correcting errors at the morphological and syntactic levels they made in their writing assignments.

The comparison of the number of errors at the pretest and posttest stages is further explored to decide if this method has positive effects on the writing skill in terms of minimization of errors during the course of the study. Thus, the number of errors at the pretest and posttest stages was examined quantitatively. The pretest and posttest were similar; there were similar trigger questions, but the themes were different. The theme discussed in the pretest was Wohn- und Lebenssituationen, but the theme in the posttest was Uni oder Ausbildung. The similar trigger questions include asking how a person is doing, asking for advice, mentioning the advantages and disadvantages of an option, and the use of the Konjunktiv II mood to suppose if the participants were in the positions of the characters in the text. The given time allocation and applied rules were the same between the pretest and posttest. Due to such similarities, different themes for the writing assignments in the pretest and posttest should not be an issue and would not cause different levels of difficulty. Besides, the themes had also been discussed in the class beforehand.

After learning how to recognize and correct morphological and syntactic errors independently with the assistance of correction codes at the correction stage, participants were asked once again to do similar tasks in the posttest to investigate the effectiveness of the indirect correction method in the minimization of errors during the course of the study. The expected effectiveness in this regard is that at least $50 \%$ of the participants experience a reduction in the number of errors in the posttest. However, after the number of errors each participant made in the pretest and posttest was compared, only 16 participants (43\%) experienced a reduction in the number of errors. Meanwhile, 21 other participants experienced an increase in the number of errors. As less than half of the participants experienced the reduced number of errors, it can be argued that the indirect correction method is not effective in minimizing errors over the course of the study.

The proportion of the number of errors in the posttest can also be discovered accumulatively by the type of errors through the following table, where there is both decrease and increase in the number of certain types of errors.

Table 6. The comparison of the number of errors in the pretest and posttest

\begin{tabular}{clccc} 
No. & \multirow{2}{*}{ Type of Errors } & \multicolumn{2}{c}{ Total } & \multirow{2}{*}{ Difference } \\
\cline { 3 - 4 } & & Pretest & Posttest & \\
\hline 1. & Semantic/syntactic reference & 83 & 92 & 9 \\
\hline 2. & Genus & 31 & 43 & 12 \\
\hline 3. & Case & 50 & 47 & -3 \\
\hline 4. & Conjunction & 9 & 13 & 4 \\
\hline 5. & Mood & 10 & 8 & -2 \\
\hline 6. & Morphological error & 12 & 24 & 12 \\
\hline 7. & Modal verb & 1 & 0 & -1 \\
\hline
\end{tabular}




\begin{tabular}{clccc}
\hline 8. & Preposition & 26 & 27 & 1 \\
\hline 9. & Pronoun & 4 & 1 & -3 \\
\hline 10. & Orthography & 86 & 107 & 21 \\
\hline 11. & Sentence structure & 32 & 39 & 7 \\
\hline 12. & Sentence position & 59 & 57 & -2 \\
\hline 13. & Tempus & 10 & 13 & 3 \\
\hline 14. & Punctuation & 46 & 42 & -4 \\
\hline 15. & Missing element & 49 & 53 & 4 \\
\hline
\end{tabular}

It can be clearly seen from the table above that a few types of errors increased. This can be caused by several factors, including the lack of habituation to recognize and correct errors independently as this method has never been applied to this group of participants before; the limited amount of time to do the writing assignments; participants' lack of grammar knowledge; and also language interference. The factors causing the increase or decrease in the number of errors, however, were not further investigated in this study. This study also found that there were 6 types of errors with the decreasing number of errors, namely case, mood, modal verb, pronoun, sentence structure, and punctuation. The errors in case, mood, and punctuation had the highest rate of successful correction at the correction stage. Errors in modal verbs were 1 out of 3 types of errors that had the lowest rate of successful correction. Meanwhile, the type of errors that experienced a significant increase in the posttest was orthographical errors with a total of 21 errors, followed by morphological errors with a total of 12 errors where participants wrote words that do not exist in German; and errors in genus in which participants incorrectly used articles with a total of 12 errors.

\section{CONCLUSION}

Based on the comparison of the results of the pretest and correction stages as well as the error analysis, it can be concluded that the use of correction codes in the indirect correction method for errors is quite useful in helping participants recognize and correct errors at the morphological and syntactic levels in the writing assignments. This study found that 12 out of 15 types of errors had at least a $50 \%$ rate of successful correction. Errors in punctuation, mood, and case had the highest successful correction rates at the correction stage. Meanwhile, errors with a successful correction rate below 50\% were errors in modal verb, sentence structure, and missing element; these types of errors are quite difficult be corrected because the correction involves more complicated process than just replacing one or two words or adding a suffix. These types of errors will be more difficult to be corrected if they are not well thought out, or participants' grammar knowledge is still lacking.

The number of participants with a decreasing number of errors in the posttest was only $43 \%$ or 16 people out of 37 participants. The data suggest that indirect correction method is not adequately effective in minimizing errors at the morphological and syntactical levels during the course of the study. The factors contributing to these results include the limited time allocation for the tasks, the limited knowledge of grammar, first language interference, and the lack of 
habituation in independently recognizing and correcting errors since the method has only been applied to this group of participants for the first time.

Habituation is necessary; thus, the benefits of engaging learners with errors through indirect correction method can finally be derived after repeated implementation. This method can be tried repeatedly over a longer period of time. However, each participant's language ability should be ensured equal if the effectiveness of this method in improving writing skill will also be assessed.

\section{REFERENCES}

Brachmann-Bosse, S. (2019). Lernmotivierende Formen der Fehlerkorrektur bei der mündlichen Produktion im DaF-Unterricht. Zeitschrift des bulgarischen Deutschlehrerverbandes (BDV Magazin), April 2019, 16-20.

Buckingham, L., \& Aktuğ-Ekinci, D. (2017). Interpreting coded feedback on writing: Turkish EFL students' approaches to revision. Journal of English for Academic Purposes, 26, 1-16. https://doi.org/10.1016/j.jeap.2017.01.001

Dreyer, H., \& Schmitt, R. (2013). Lehr- und Übungsgrammatik der deutschen Grammatik. Die Gelbe aktuell. Ismaning: Hueber Verlag.

Fang, F., \& Freudenberg-Findeisen, R. (2019). Wie verarbeiten Lernende Dozentenfeedback und welches Feedback ist für Lernende effektiv?, Informationen Deutsch als Fremdsprache, 46(2), 256-286. https://doi.org/10.1515/infodaf-20190019

Gračner, D. M. (2018). Fehler beim schriftlichen Produzieren von Texten im DaFStudium. Eine empirische Untersuchung am Beispiel slowenischer Germanistikstudierender. Journal for Foreign Languages, 10(1), 219-237. https://doi.org/10.4312/vestnik.10.219-237

Helbig, G., \& Buscha, J. (1996). Deutsche Grammatik. Ein Handbuch für den Ausländerunterricht. Leipzig: Verlag Enzyklopädie.

Kalkan, H. K. (2018). Eine Studie zur fehleranalytischen Kompetenz der Studierenden in der Deutschlehrendenausbildung. Diyalog Interkulturelle Zeitschrift Für Germanistik, 6(1), 97-113. https://dergipark.org.tr/en/pub/diyalog/issue/38314/443564

Kanzian, H. (2019). Fehlerkultur im Deutschunterricht [Diplomarbeit] https://netlibrary.aau.at/obvuklhs/content/titleinfo/5326503/full.pdf

Klambauer, L. (2019). Fehler werden gemacht, um aus ihnen zu lernen [Doctoral dissertation, Universität Wien]. doi: 10.25365/thesis.58391

Klemm, A. (2019). Wie nützlich sind schriftliche Korrekturen grammatischer Fehler im DaF-Unterricht?: Annäherung an eine praxisrelevante Frage. Deutsch als Fremdsprache, 56(1), 2. https://doi.org/10.37307/j.2198-2430.2019.01.03

Kleppin, K. (2002). Fehler und Fehlerkorrektur. Berlin, München, Wien, Zürich, New York: Langenscheidt.

Koeva, J. (2019). Fehlerkorrektur in Partnerarbeit und Kleingruppen bei schriftlich fixierten Texten. Zeitschrift des bulgarischen Deutschlehrerverbandes (BDV Magazin), April 2019, 21-27.

Miniböck, E. (2018). Schriftliche Fehlerkorrektur von DaZ-Schülerinnen und-Schülern: eine Analyse von impliziten schriftlichen Fehlerkorrekturtechniken anhand von 
authentischen Schreibaufgaben [Doctoral dissertation, Universität Wien]. doi: 10.25365/thesis. 51975

Ondráková, J., \& Pazlarová, A. (2017). Fehleranalyse in den schriftlichen Klausuren der Bachelorstudenten. Zentrum und Peripherie: aus fremdsprachendidaktischer Sicht, 97-108.

Pedrazzini, G. (2018). Umgang mit schriftlichen Fehlern im schülerzentrierten DaFUnterricht am Gymnasium. Zwei Vorschläge [Doctoral dissertation, Scuola universitaria professionale della svizzera italiana (SUPSI)]. http://tesi.supsi.ch/id/eprint/2235

Perdamean, A. S. (2017). Bentuk-bentuk Kesalahan Tata Bahasa Jerman Melalui Penerapan Analisis Kesalahan (Fehleranalyse). Prosiding Seminar Hilirisasi Penelitian Untuk Kesejahteraan Masyarakat Lembaga Penelitian Universitas Negeri Medan, 33-39.

Pittner, K., \& Berman, J. (2010). Deutsche Syntax: ein Arbeitsbuch. 4. Auflage. Tübingen: Narr Francke Attempto Verlag GmbH + Co. KG.

Pujiawati, N. (2018). The use of indirect corrective feedback to eliminate the grammatical errors in students' writing. Journal of English Language Studies, 3(1), 41-50. http://dx.doi.org/10.30870/jels.v3i1.3102

Ramírez Balderas, I., \& Guillén Cuamatzi, P. (2018). Self and Peer Correction to Improve College Students Writing Skills. Profile: Issues in Teachers' Professional Development. http://dx.doi.org/10.15446/profile.v20n2.67095 